\title{
The Influence of Precursor Plants to Protein and Gluten of Fall Wheat
}

\author{
Ergashev N. Yu. ${ }^{1}$, Khalikov B. M. ${ }^{2}$ \\ Research Institute of Cotton Breeding, Seed Production and Growing Agrotechnologies, Tashkent, Uzbekistan
}

\begin{abstract}
In this article we brought results about influence of periodic plants and measures of mineral fertilizers to protein and gluten in fall wheat. According to the taken information, the highest amount of protein and gluten was planted after fall wheat, soybean and golden gram, and mineral fertilizers were taken after caring of $N_{150} P_{105} K_{75} \mathrm{~kg}$ and these indicators were formed 16,1-16,0\%.
\end{abstract}

Keywords: fall wheat, soybean, golden gram, mineral fertilizers, grain, productivity

\section{Introduction}

Nowadays the only way to provide the need of population is to widen planting areas and take as much as can and highquality harvest from each hectare. New intensive technologies and provision farmers with quality seeds have important role to overcome such kind of tasks. The seed keeps biologic and economic features of the plant. That's why the harvest depends on the quality of seed.

Wheat fields are cleared early and for that reasons there is a possibility to sow periodic plants and take harvest twice in a year. In order to use irrigated areas efficiently it is necessary to work out and introduce agro techniques of many periodic crops, fodder crops, butyric and other plants in production.

Using irrigated areas efficiently all year around not only provides with increasing the productivity but also helps to increase soil productivity, to improve its ameliorative state and to decrease the pollution of environment with chemicals. It is important to note that Fergana valley in soil-climate condition the role of periodic plants have not been identified according to the amount of stubbles and roots in soil and sowing methods. That's why the main issue is to study planting dates, methods of fall wheat which is sowed after periodic plants (golden gram, soybean and Indian maize) in stubble and also the influence and productivity of fertilizer measures in taking high and quality crop seeds from fall wheat in pasturable soil conditions of Fergana region.

\section{Methods and Materials}

Field experiments take place in pasturable, mechanically hard sandy, waters in 1,6-1,7 $\mathrm{m}$ deep areas of Fergana region. Research works were taken place in field number M8/1 of the Fergana branch of RICBSP\&GA in 2010-2013 and were studied the influence of periodic plants as Indian corn, soybean and golden gram to growing, developing, productivity and quality of fall wheat.

Experiment consists of 12 variations, 4 repetition and variations are arranged in one circle. Total area of each variation is $4,8 \times 50 \mathrm{~m}=240 \mathrm{~m}^{2}$, measure $120 \mathrm{~m}^{2}$, total area of experiment is 1,2 ha.
We have used «Agrophysical Research Methods of Soil» (1963) manual to analyze agrophysics of soil and «Agrochemical Analysis Methods of Soils and Plants» (1982) manual for chemical analyses. The amount of rests from root and stubble which gathers after fall wheat and periodic plants are identifies by washing and drying soil monolith before experiment. To make observations of fall wheat it was used «Method of State Quality Testing of Agricultural Products» manual (1980), mathematic analyses to the information of periodic plants and fall wheat productivity were treated by the method of B.A.Dospekhov (1964). Expenses and profits to grow of periodic plants and fall wheat it was used the «Economic Effectiveness Identifying Method of Using Scientific Research Results in Agriculture» manual.

\section{Research Results}

According to the information of crop quality indicators which belongs to periodic plants and fertilizer measures of fall wheat, we identified the amount of protein in crop is 14,$5 ; 15,2$ and $14,8 \%$, from 1 hectare 0,$79 ; 0,82$ and 0,80 tons is equal to 1,$3 ; 1,4$ and 1,3 tons in accordance with fertilizer measures in control variation of experiment. So, higher indicators are taken when used $\mathrm{N}_{200} \mathrm{P}_{140} \mathrm{~K}_{100} \mathrm{~kg} / \mathrm{ha}$ measures.

It is important to note that, sufficient degree of protein and gluten in crop has great importance in agriculture and it cannot be produced food products as macaroni, vermicelli from flour with less gluten. That's why the crop harvest from fall wheat should be qualitative.

So, in very many researches were identified the importance of crops among leguminous periodic plants. High quality crop harvest also was taken from fall wheat which was sowed after soybean and golden gram in our experiments. After these plants in fall wheat $\mathrm{N}_{200} \mathrm{P}_{140} \mathrm{~K}_{100} \mathrm{~kg} / \mathrm{ha}$ the mount of protein is $16,1-16,0 \%$, in a hectare $0,89-0,88$ tons, the amount of gluten $29,2-29,0 \%$, in a hectare $1,8-1,8$ tons.

These indicators were identified according to 2 variation of control proportion $\left(\mathrm{N}_{200} \mathrm{P}_{140} \mathrm{~K}_{100} \mathrm{~kg} / \mathrm{ha}\right) 0,9-0,8 \%$ and were higher to 0,07-0,06 tons. But, in the crop of fall wheat which sowed after Indian maize the amount of protein is $15,9 \%$ and 0,84 tons, gluten $28,2 \%$ and 1,5 tons, and higher to (2) $0,7 \%$ and 0,2 tons and $0,3 \%$ and 0,2 tons; by the influence of

\section{Volume 6 Issue 12, December 2017}




\section{International Journal of Science and Research (IJSR) \\ ISSN (Online): 2319-7064 \\ Index Copernicus Value (2016): 79.57 | Impact Factor (2015): 6.391}

soybean and golden gram it is less than $0,2-0,1 \%$ and $0,5-$ $0,4 \%$ and also $1,0-0,8 \%, 0,3-0,3$ tons (table).

According to the information taken in food units and protein amount from crop and straw quality indicators of fall wheat periodic plants show high indicators than in other variations when they nourish fall wheat which sows after soybean with mineral fertilizers $\mathrm{N}_{150} \mathrm{P}_{105} \mathrm{~K}_{75} \mathrm{~kg} / \mathrm{ha}$, and the nourishment unit is $75,2 \mathrm{~kg} / \mathrm{ha}$, the amount of protein digestion is 8,4 $\mathrm{kg} / \mathrm{ha}$ such kind of information were $(75,6-8,3 \mathrm{~kg} / \mathrm{ha})$ also taken when periodic plant was sowed after golden gram. These indicators proportional to 7,5-4,5 and 8,9-1,4 kg/ha control were high. The nourishment unit and the amount of protein digestion in crops structure of fall wheat which were sowed after Indian maize are less than in other variations and differs to $0,3-(-0,1) \mathrm{kg} / \mathrm{ha}$ from control.

Nourishment unit and the amount of protein in straw structure are less to 4-5 and 10-12 times than grain indicator, but differences between variations stays as in crops.

Table: The influence of periodic plants and fertilizer measures to the amount of protein and gluten in crops structure of fall wheat.

\begin{tabular}{|c|c|c|c|c|c|c|c|c|}
\hline \multirow[t]{2}{*}{ Variation } & \multirow[t]{2}{*}{ Periodic plants } & \multicolumn{3}{|c|}{$\begin{array}{l}\text { Measures of mineral } \\
\text { fertilizers in fall wheat, } \mathrm{kg} / \mathrm{h}\end{array}$} & \multirow{2}{*}{$\begin{array}{c}\text { The amount of } \\
\text { protein, } \%\end{array}$} & \multirow{2}{*}{$\begin{array}{l}\text { Protein from a } \\
\text { hectare, tons }\end{array}$} & \multirow{2}{*}{$\begin{array}{l}\text { Amount of } \\
\text { gluten } \%\end{array}$} & \multirow{2}{*}{$\begin{array}{l}\text { Gluten from a } \\
\text { hectare, tons }\end{array}$} \\
\hline & & $\mathrm{N}$ & $\mathrm{P}_{2} \mathrm{O}_{5}$ & $\mathrm{~K}_{2} \mathrm{O}$ & & & & \\
\hline 1 & \multirow{3}{*}{$\begin{array}{c}\text { Periodic plant was } \\
\text { not sowed }\end{array}$} & 150 & 105 & 75 & 14,5 & 0,79 & 27,6 & 1,3 \\
\hline 2 & & 200 & 140 & 100 & 15,2 & 0,82 & 27,9 & 1,3 \\
\hline 3 & & 250 & 175 & 125 & 14,8 & 0,80 & 27,8 & 1,3 \\
\hline 4 & \multirow{3}{*}{$\begin{array}{c}\text { Soybean } \\
\mathrm{N}_{60} \mathrm{P}_{90} \mathrm{~K}_{60} \mathrm{~kg} / \mathrm{ha}\end{array}$} & 150 & 105 & 75 & 16,1 & 0,89 & 29,2 & 1,8 \\
\hline 5 & & 200 & 140 & 100 & 15,9 & 0,84 & 28,9 & 1,4 \\
\hline 6 & & 250 & 175 & 125 & 15,8 & 0,83 & 28,0 & 1,5 \\
\hline 7 & \multirow{3}{*}{$\begin{array}{c}\text { Golden gram } \\
\mathrm{N}_{60} \mathrm{P}_{90} \mathrm{~K}_{60} \mathrm{~kg} / \mathrm{ha}\end{array}$} & 150 & 105 & 75 & 16,0 & 0,88 & 29,0 & 1,8 \\
\hline 8 & & 200 & 140 & 100 & 15,8 & 0,83 & 28,2 & 1,8 \\
\hline 9 & & 250 & 175 & 125 & 15,8 & 0,83 & 28,0 & 1,5 \\
\hline 10 & \multirow{3}{*}{$\begin{array}{c}\text { Indian maize } \\
\mathrm{N}_{200} \mathrm{P}_{140} \mathrm{~K}_{100} \mathrm{~kg} / \mathrm{ha}\end{array}$} & 150 & 105 & 75 & 14,8 & 0,80 & 28,0 & 1,5 \\
\hline 11 & & 200 & 140 & 100 & 15,5 & 0,81 & 28,1 & 1,4 \\
\hline 12 & & 250 & 175 & 125 & 15,9 & 0,84 & 28,2 & 1,5 \\
\hline
\end{tabular}

\section{Conclusion}

It is recommended to sow wheat after periodic leguminous crops as golden gram and soybean in order to take qualitative grain harvest with high protein and gluten from fall wheat in pasturable soil conditions of Fergana region and use and care fertilizers in $\mathrm{N}_{150} \mathrm{P}_{105} \mathrm{~K} 75 \mathrm{~kg} / \mathrm{ha}$ measures.

\section{References}

[1] Juraev K., Khaydarov A., Rakhmatullaev G. The Growing, Developing of Fall Wheat and Crop Productivity in Periodic Sowing System. // ScientificTraining Materials of the Republic.- Tashkent, 2013.- P. 202-204.

[2] Nuriddinov N., Shamsiddinov F. The Influence of Soybean to Soil Productivity. Scientific-Training Materials of the Republic. // Tashkent, 2013.- P. 175178.

[3] Khalikov B., Namozov F. Scientific Analyses of Precursor Planting. // Tashkent, 2016.- P. 222.

[4] Khalikov B.M. The Productivity of Modern Periodic Sowing Systems in Increasing Soil Effectiveness. // Collected Papers of the UzRICG.- Tashkent, 2013.- P. 130 . 